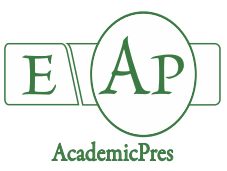

Zandi P et al. (2020)
Notulae Botanicae Horti Agrobotanici Cluj-Napoca 48(4):2060-2071
DOI:10.15835/48412081
Research Article

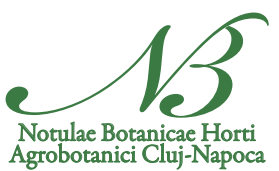

\title{
Allelopathic effect of invasive Canadian goldenrod (Solidago canadensis L.) on early growth of red clover (Trifolium pratense L.)
}

\author{
Peiman ZANDI ${ }^{1,2}$, Beata BARABASZ-KRASNY ${ }^{3}$, Alina \\ STACHURSKA-SWAKOŃ ${ }^{4}$, Joanna PUŁA ${ }^{5}$, Katarzyna MOŻDŻEŃ ${ }^{3 *}$
}

\author{
${ }^{1}$ Yibin University, International Faculty of Applied Technology, Yibin, Sichuan, 644600, China; z_rice_b@yahoo.com \\ ${ }^{2}$ Institute of Environment and Sustainable Development in Agriculture, Chinese Academy of Agricultural Science, Beijing, China; \\ ${ }^{3}$ Pedagogical University of Krakow, Institute of Biology, Podchorązych 2 St.,30-084 Kraków, Poland; beata.barabasz- \\ krasny@up.krakow.pl; katarzyna.mozdzen@up.krakow.pl ("correspondingauthor) \\ ${ }_{4}^{4}$ Jagiellonian University, Institute of Botany, Gronostajowa St. 3, 30-387 Kraków, Poland; alina.stachurska-swakon@uj.edu.pl \\ ${ }^{5}$ University of Agriculture, Faculty of Agriculture and Economics, Al. Mickiewicza 21 Ave, 31-120 Kraków, \\ Poland; joanna.pula@urk.edu.pl
}

Abstract

Solidago canadensis belongs to highly invasive species in Europe, it is established in ruderal, semi-natural and natural communities. To test the traits related to invasiveness, the experiment with the potential of allelopathic compounds produced by the species was conducted. The aqueous extract from the goldenrod leaves was used to examine the germination and early stages of development of Trifolium pratense, the species as an example of fodder plant common in meadows and pastures. Three types of aqueous extract were used: decoction, infusion, and macerate. All extracts of Canadian goldenrod had a negative influence on the germination process of red clover, however, the effect changed in time and type of extract. The most inhibiting influence was documented for the macerate type of aqueous extract. Similarly, the negative influence of macerate was the highest for the length and weight of the seedlings, the content of chlorophyll $a$ and $b$, and electrolyte leakage. As the procedure of obtaining the macerate is the most like the process of natural extraction of allelopathic substances in nature, there is the practical conclusion to remove the moved biomass of the goldenrod during the restoration process of areas colonised by the species.

Keywords: allelopathy; chlorophyll; electrolyte leakage; germination; invasive species; leaves exudates

\section{Introduction}

Invasions of alien species is a worldwide serious ecological problem leading to changes in biodiversity and ecosystem functioning (Pejchar and Mooney, 2002; Pyšek and Richardson, 2010; Pyšek et al., 2010). Invasions also influence a local economy (Pimentel, 2011) and they are an important task for nature conservation (Soltys-Lelek and Barabasz-Krasny, 2010). The invasive success of non-native plants depends on their biological traits and the vulnerability of the ecosystem (Rejmánek et al., 2005; Bartoszek and StachurskaSwakoń, 2016). Natural disturbances and anthropogenic changes in environments or in management alter the possibility of invasiveness (Hobbs, 2000; Trzcińska-Tacik and Stachurska-Swakoń, 2011). Allelopathic 
compounds produced by plants are considered as an additional element facilitating competition for invasive species during settlements (Abhilasha et al., 2008; Yuan et al., 2013).

Solidago canadensis L. s.l. (Canadian goldenrod) is one of the successful invaders of North America origin that colonised large areas across Europe, Asia, Australia, New Zealand (Semple and Cook, 2006; Lu et al., 2007; Abhilasha et al., 2008; Yuan et al., 2013). The species occurs in ruderal, semi-natural and natural communities, especially in moist habitats (Guzikowa and Maycock, 1986; Zając and Zając, 2015; Towpasz and Stachurska-Swakoń, 2018). It forms single-species aggregation or species-poor communities that lead to landscape homogenisation (Chen et al., 2005; Yuan et al., 2013), reducing diversity of native plant species (Szymura and Wolski, 2006; Szymura et al., 2018) and animals, mainly insects and birds (Moroń et al., 2009; Skórka et al., 2010; Masło and Najberek, 2014).

Comprehension of the invasion mechanism of $S$. canadensis is an important issue in the management and recultivation of the areas colonised with the goldenrod. The species propagates vegetatively by rhizomes forming large clonal colonies and produces a huge number of small seeds easily dispersed by wind (VoserHuber, 1983; Rosef et al., 2019). The rhizomes of the species produce substances that suppress soil pathogens (Zhang et al., 2009). There are few studies testing the allelopathic potential of the Canadian goldenrod (Butcko and Jensen, 2002; Sun et al., 2006; Abhilasha et al., 2008; Yuan et al., 2013; Domaradzki et al., 2017). The aim of the current experiment was to check if the allelopathic compounds from decaying biomass of goldenrod could inhibit the native species. For this experiment, meadow red clover (Trifolium pratense L. cv. 'Rozeta') from the Fabaceae family was selected as a fodder plant species of economic importance, due to its feed qualities. The aim of the study was to examine the effect of three types of $S$. canadensis leaf extracts in the form of decoction, infusion and macerate on seed germination and early growth of $T$. pratense. The following parameters were determined: germination indexes (1), the seedlings length (2), the fresh and dry weight and water content (3) the chlorophyll content (4) and the degree of cell membrane destabilisation by electrolyte leakage method (5).

\section{Materials and Methods}

\section{Plant material}

Trifolium pratense L. cv. 'Rozeta' (fodder, diploid cultivar, characterised by quite tall plants, prone to lying on ground) seeds were obtained from the Sadowniczy store (Poland). The Solidago canadensisleaves were collected in the south-eastern part of Poland - Suchoraba $49^{\circ} 58^{\prime} 37^{\prime \prime} \mathrm{N} 20^{\circ} 11^{\prime} 49^{\prime \prime} \mathrm{E}$.

\section{Extracts preparation}

The aqueous extracts of goldenrod leave in the form of infusion (crushed dry leaves flooded with hot water), decoction (crushed dry leaves boiled in water) and macerate (crushed dry leaves flooded with water and left to stand) were prepared according to the method used by Czerwińska et al. (2015). The infusion was prepared from $5 \mathrm{~g}$ of dry $S$. canadensis leaves, which were poured over with $250 \mathrm{ml}$ of boiling distilled water and left covered for $30 \mathrm{~min}$. After cooling, the extract was filtered through filter papers. The decoction was prepared by weighing out $8.75 \mathrm{~g}$ of dry plant material, which was poured with a 1 litre of distilled water. The solution was mixed thoroughly and left for $24 \mathrm{~h}$ in the dark, at room temperature $\left(20-25^{\circ} \mathrm{C}\right)$. After one day, the aqueous extract was boiled for $15 \mathrm{~min}$ and filtered in the same way as the infusion. Extract in the form of a macerate was prepared by flooding $5 \mathrm{~g}$ of dry leaves of $100 \mathrm{ml}$ cold distilled water and left in the dark, at room temperature for $24 \mathrm{~h}$. After one day, the extract was filtered the same form like as infusion and decoction. The extracts were stored during the experiment at $8{ }^{\circ} \mathrm{C}$. 


\section{Germination conditions}

The Petri dishes experiment was performed as follows: clover seeds were rinsed in a $1 \%$ acetone solution, followed by distilled water and put into sterile dishes $(\varnothing 9 \mathrm{~cm})$ with three layers of filter paper $(50$ seeds per dish). Each Petri dish was soaked in $6 \mathrm{ml}$ of the appropriate extract and watered with $3 \mathrm{ml}$ of extract every other day. The control consisted of Petri dishes with seeds watered with distilled water in the same quantities as dishes with extracts. Seeds were stored in a growth chamber (Angelantoni Industrie, Italy) at $25^{\circ} \mathrm{C} / 20^{\circ} \mathrm{C}$ temperature (day/night), with $200 \mu \mathrm{mol} \cdot \mathrm{m}^{-2} \cdot \mathrm{s}^{-1}$ light intensity and relative humidity $\mathrm{RH} \%$ 60-70\%, during 8 days. The experiment was carried out in 3 repetitions in 2 independent series.

\section{Germination indexes}

Germination rate (GR), germination speed (GS), allelopathic effect response index (RI) (Gao et al., 2009) and seedling vigour index (SVI) (Islam et al., 2009).

$\mathrm{GR}=($ number of germinated seeds $/$ total number of seeds $) \times 100$

$\mathrm{GS}=((\mathrm{GT} \times \mathrm{D}) /(\mathrm{GC} \times \mathrm{D})) \times 100$

where: GT is the number of germinated seeds daily in the treatment, GC is the number of germinated seeds daily in the control, and $\mathrm{D}$ is the number of corresponding days

$\mathrm{RI}=1-\mathrm{C} / \mathrm{T}($ when $\mathrm{T} \geq \mathrm{C})$

where: $\mathrm{C}$ is the control germination speed and $\mathrm{T}$ is the treatment germination speed

SVI $=($ seedling length $(\mathrm{cm}) \times$ percentage of germinated seeds $) / 100$.

\section{Biometric analysis}

The length of T. pratense (root and hypocotyl) seedlings treated the aqueous extracts from $S$. canadensis was measured using a calliper (Topex $31 \mathrm{C} 615$, Poland), to the nearest of $0.1 \mathrm{~cm}$, after the 8 days from start of the experiment. The inhibition of percentage growth (IP), expressed as a percentage of control seedlings index, was determined according to formula used by Mominul Islam and Kato-Noguchi (2012).

\section{Fresh and dry weight and tissue water content}

Seedlings were weighted (fresh weight - FW) (Radwag WPS120, Poland) and dried (dry weight - DW) at $105^{\circ} \mathrm{C}$ for $48 \mathrm{~h}$ in oven (Wamed SUP 100, Poland). Tissue water content (TWC) was studied according to Black and Pritchard (2002) with some modifications.

\section{Chlorophyll content}

The content of chlorophyll $a, b, a+b$ was determined according to Barnes et al. (1992). The aboveground parts of the seedlings were extracted in dimethyl sulfoxide (SIGMA-Aldrich) at $65^{\circ} \mathrm{C}$ for 12 hours. The absorbance of chlorophyll $a$ and $b$ was determined at the wavelength: $\lambda=665$ and $648 \mathrm{~nm}$, using a spectrophotometer Aquarius 9500 (Cecil Instruments, Cambridge, United Kingdom).

\section{Electrolyte leakage}

The degree of cell membranes destabilisation by the electrolyte leakage was carried out on clover seedlings according to the method described by Redmann et al. (1986).

\section{Statistical analysis}

The importance of variability between objects by Anova was checked. The analysis of the differences between groups was examined by Duncan test for homogeneous groups, at the level of $\mathrm{p} \leq 0.05$; values marked with different letters $(\mathrm{a}, \mathrm{b}, \mathrm{c})$ differ significantly. The calculations were performed using Statistica for Windows 13.1. 


\section{Results}

\section{Germination indexes}

Compared to the control, in 8 days, the highest germination rate (GR) values were found in seeds grown on the Solidago canadensis decoction. The lowest values of germinated Trifolium pratensecv. Rozeta seeds was observed in Petri dishes with macerate. Germination speed (GS), expressed as a percentage of control, was significantly highest for seeds watered with decoction, and the lowest for seeds on the macerate. Allelopathic effect response index (RI) showed that decoction has a positive influence on seed germination. In turn, the infusion and macerate inhibited clover seed germination. Compared to the control, the highest inhibitory effect was observed for seeds watered with macerate. The seedling vigour index (SVI) was significantly highest for the control in relation to the extracts used. Regardless of the examined seedlings organ, the infusion and macerate resulted in a significant reduction the SVI (Figure 1, Table 1).

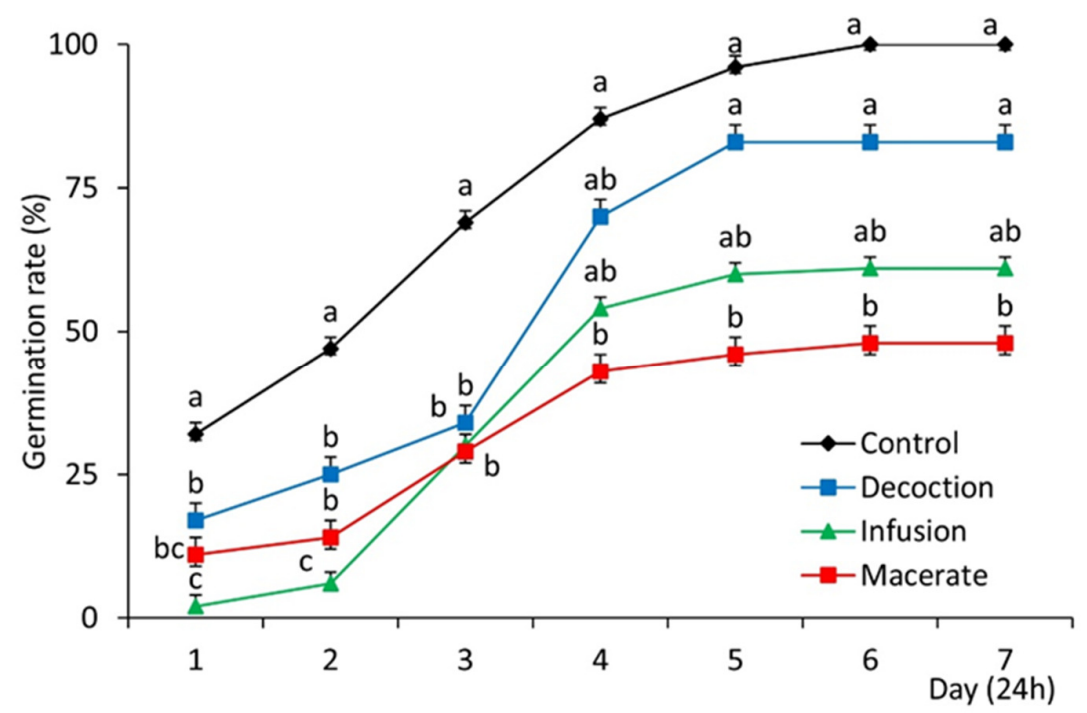

Figure 1. Germination rate (GR) of Trifolium pratense L. cv. 'Rozeta' seeds, treated with different types of Solidago canadensis L. aqueous extracts from dry leaves

Mean values $( \pm S D)$ marked in different letters $(a, b, c)$ differ significantly according to Duncan's test $\mathrm{p} \leq 0.05$

Table 1. Germination speed (GS) expressed as a percentage of control, allelopathic effect response (RI) and seedling vigour index (SVI) of Trifolium pratense L. cv. 'Rozeta' seeds treatment different types of Solidago canadensis L. aqueous extracts from dry leaves

\begin{tabular}{|c|c|c|c|c|}
\hline Parameters & Control & Decoction & Infusion & Macerate \\
\hline GS (\%) & 100 & $70.29 \pm 0.82 \mathrm{a}$ & $45.06 \pm 0.80 \mathrm{~b}$ & $43.41 \pm 0.84 \mathrm{~b}$ \\
\hline RI (a.u.) & $0 \pm 0.00 \mathrm{~b}$ & $0.40 \pm 0.02 \mathrm{a}$ & $-1.08 \pm 0.06 \mathrm{c}$ & $-1.50 \pm 0.11 \mathrm{~d}$ \\
\hline SVI whole seedling (a.u.) & $2.95 \pm 0.81 \mathrm{a}$ & $2.29 \pm 0.70 \mathrm{a}$ & $0.28 \pm 0.05 \mathrm{~b}$ & $0.19 \pm 0.07 \mathrm{~b}$ \\
\hline SVI root (a.u.) & $1.25 \pm 0.33 \mathrm{a}$ & $1.15 \pm 0.42 \mathrm{a}$ & $0.14 \pm 0.05 \mathrm{~b}$ & $0.08 \pm 0.04 \mathrm{~b}$ \\
\hline SVI hypocotyl (a.u.) & $1.70 \pm 0.54 \mathrm{a}$ & $1.14 \pm 0.38 \mathrm{a}$ & $0.14 \pm 0.04 \mathrm{~b}$ & $0.11 \pm 0.03 \mathrm{~b}$ \\
\hline
\end{tabular}

Note: mean values $( \pm S D)$ marked in different letters $(a, b, c)$ in row differ significantly according to Duncan's test $\mathrm{p} \leq$ 0.05

\section{Biometric analysis}

Biometric analysis of $T$. pratense seedlings revealed a statistically inhibitory effect of aqueous extracts from $S$. canadensis leaves (Figure 2). On the macerate, a significant growth inhibition for the above- and underground organs of seedlings was observed. Regardless of the type of extracts, the growth of the aboveground organs was inhibited, compared to the control. Analysis of the length of whole clover seedlings 
showed a negative impact of each of the extracts. Compared to the control, no significant differences in length seedling growth were observed for $T$. pratense germinated on the decoction.
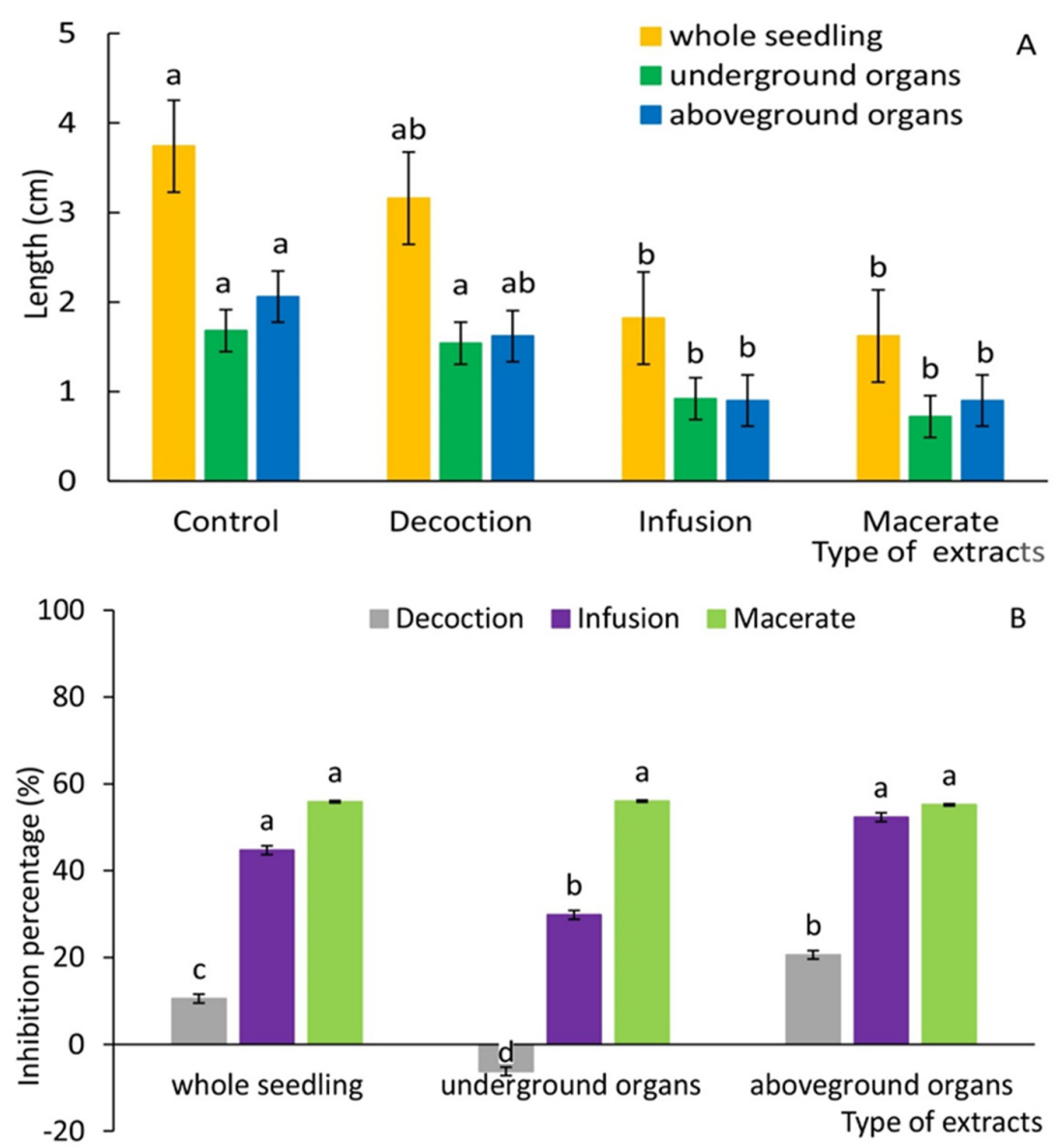

Figure 2. Length of seedlings (cm) (A) and inhibition percentage index IP (B), of Trifolium pratense L. cv. Rozeta seedlings, which were treated with different types of Solidago canadensis $\mathrm{L}$. aqueous extracts from dry leaves

Mean values $( \pm S D)$ marked different letters $(a, b, c)$ differ significantly according to Duncan's test $p \leq 0.05$; $(B)$ - a negative $(-)$ value indicates stimulation of growth, and a positive $(+)$ value indicates growth inhibition

\section{Fresh and dry weight and tissue water content}

The fresh weight values of $T$. pratense seedlings revealed a statistically significant negative effect of extracts on biomass increase, regardless of the type of extract used. Contrary to the dry weight, for which the values increased significantly for each extract compared to the control. Water content in seedlings was similar in each treatment, compared to control (Table 2).

\section{Chlorophyll content}

In clover seedlings grown on the infusion and macerate, significant differences in the chlorophyll $a$ and $b$ concentration were found. In relation to the control, the smallest chlorophyll content was found in seedlings watered with macerate. Only in the case of seedlings treated with decoction no statistically significant changes in the content of the analysed pigments were observed (Figure 3). 
Table 2. Fresh, dry weight and tissue water content in Trifolium pratense L. cv. 'Rozeta' seedlings treatment different types of Solidago canadensis L. aqueous extracts from dry leaves

\begin{tabular}{|c|c|c|c|}
\hline Type of extracts & Fresh weight $(\mathrm{g})$ & Dry weight $(\mathrm{g})$ & Tissue water content $(\%)$ \\
\hline Control & $0.0156 \pm 0.01 \mathrm{a}$ & $0.00018 \pm 0.01 \mathrm{~b}$ & $99.81 \pm 0.52 \mathrm{a}$ \\
\hline Decoction & $0.0094 \pm 0.01 \mathrm{~b}$ & $0.00045 \pm 0.01 \mathrm{a}$ & $94.69 \pm 6.14 \mathrm{a}$ \\
\hline Infusion & $0.0097 \pm 0.01 \mathrm{~b}$ & $0.00033 \pm 0.01 \mathrm{a}$ & $96.36 \pm 3.78 \mathrm{a}$ \\
\hline Macerate & $0.0094 \pm 0.01 \mathrm{~b}$ & $0.00032 \pm 0.01 \mathrm{a}$ & $96.90 \pm 3.35 \mathrm{a}$ \\
\hline
\end{tabular}

Note: mean values $( \pm S D)$ marked with different letters $(a, b, c)$ in column differ significantly according to Duncan's test $\mathrm{p} \leq 0.05$

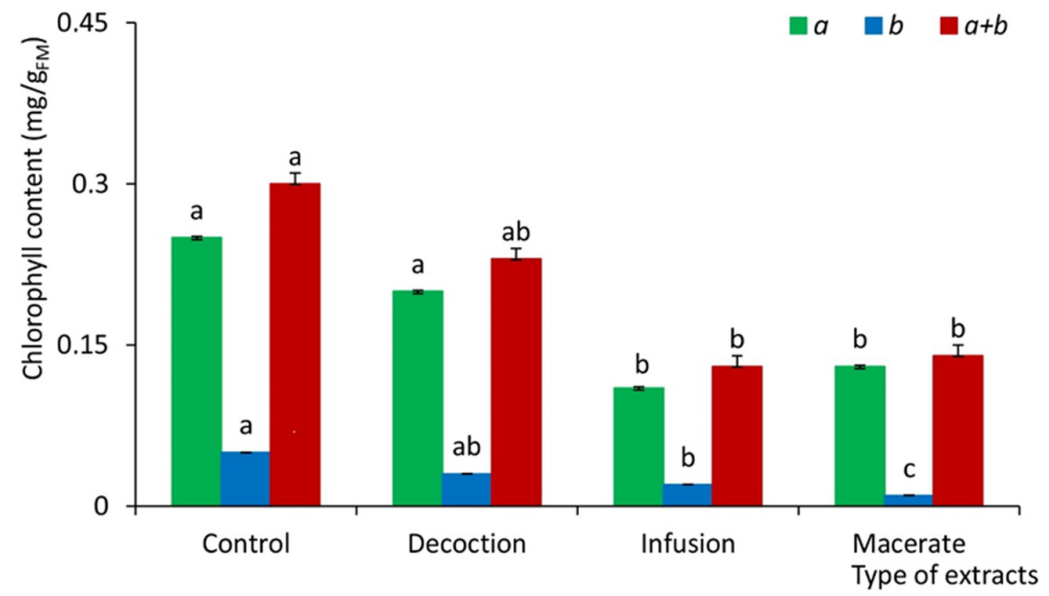

Figure 3. Content of chlorophyll $a, b, a+b$ in Trifolium pratense L. cv. 'Rozeta' seedlings treated with different types of Solidago canadensis L. aqueous extracts from dry leaves

Mean values $( \pm S D)$ marked with different letters $(a, b, c)$ differ significantly according to Duncan's test $p \leq 0.05$

\section{Electrolyte leakage}

An increase of electrolyte leakage from $T$. pratense seedlings was observed in each of the $S$. canadensis extracts used. Compared to the control, the smallest changes in water and ion management were found in seedlings watered with decoction and infusion, and the largest in seedlings germinated on macerate extracts (Figure 4).

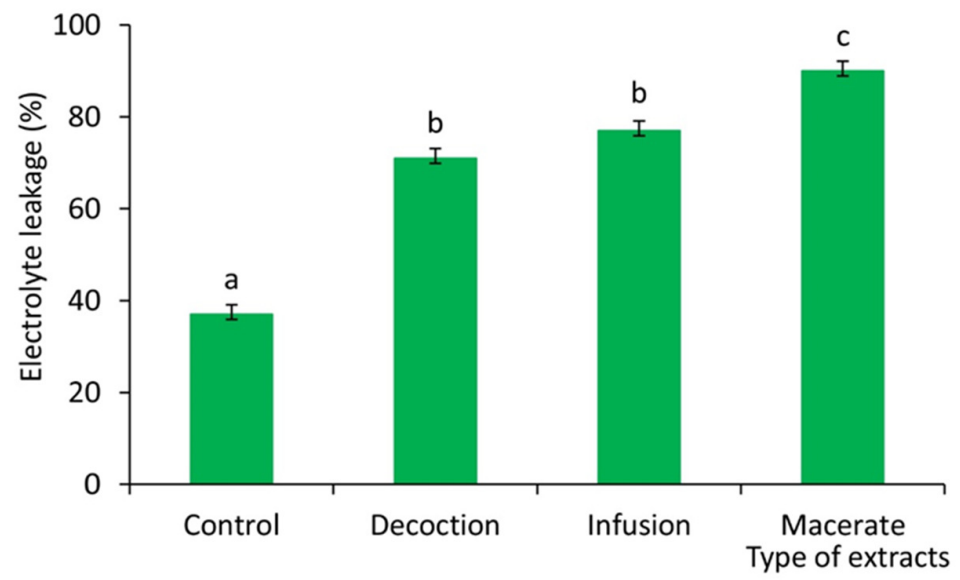

Figure 4. Electrolyte leakage in Trifolium pratense L. cv. Rozeta seedlings treated with different types of Solidago canadensis $\mathrm{L}$. aqueous extracts from dry leaves

Mean values $( \pm S D)$ marked with different letters $(a, b, c)$ differ significantly according to Duncan's test $p \leq 0.05$ 


\section{Discussion}

Alien invasive species, similarly as local weeds, form communities with an additive system of components in which individuals compete for limited habitat resources. The effect of the competition is weakening the ability of native plants to adapt to dynamic environmental conditions (Richardson and Pyšek, 2012). This is usually manifested by inhibiting seed germination, reducing the amount of biomass produced, reducing their size, disorganising of metabolic processes in plants, etc. With a strong allelopathic interaction, even individuals die from a given type of community (Hierro et al., 2003; Zandi et al., 2018, 2019; Puła et al., 2020).

In this experiment, aqueous extracts of Solidago canadensis leaves showed a pronounced inhibitory effect on the germination and growth of Trifolium pratense cv. 'Rozeta', in the early phase stages of development (Figure 1-2, Table 1). This confirms the known thesis that alien invasive plants release substances that cause allelopathic effects, influencing seed germination and the growth of native species (Tokarska-Guzik et al., 2012; Yuan et al., 2013). For example, of the 11 native species found naturally occurring in southern China, most showed sensitivity to alcoholic extracts from $S$. canadensis roots and rhizomes during germination and growth (Chen et al., 2005; Yang et al., 2007). However, the allelopathic effect was not observed for all species. It has been reported that $T$. pratense and Medicago lupulina L. react by stimulating of germination process, and during early stage of growth of red clover the stimulating of root elongation was documented. In this case, it can be concluded that root and rhizome extracts have less inhibitory properties than the various forms of leaf extracts used in the current experiment. The leaves of $S$. canadensis, as previously demonstrated, contain a wide range of compounds that may be responsible for their biological activity, among them are phenols, saponins, tannins and flavonoids (Zhao et al., 2005; Zhang et al., 2011). The leaves and other aboveground parts of various plants are the organs that produce the largest amount of this type of compound. The effect of allelopathic compounds on other plants may be negative in higher concentrations or positive in lower ones, as has been stated many times before (Inderjit and Duke, 2003; Bing-Yao et al., 2006; Inderjit et al., 2006; Sun and He, 2010; Yuan et al., 2013), and the example cited above and the current experiment clearly confirm this.

Allelopathic compounds are released into the environment from plants in the form of volatile substances, by secretion from the root system into the soil, they are also washed out or released from dead parts of plants (Barabasz-Krasny et al., 2017; Szafraniec et al., 2019; Zandi et al., 2019; Możdżeń et al., 2020; Puła et al., 2020). In this experiment, the negative effects of extracts varied depending on the type of extract used. Compared to the control, the highest inhibition of growth in length and weight of seedlings was found in the case of macerate, and the lowest in the presence of decoction (Figure 2, Table 2). Macerate is a kind of solution that most resembles the natural extraction of allelopathic substances from dead plant debris, occurring in nature. As the experiment showed, it contains a higher concentration of allelopathic compounds than the other extracts and significantly inhibits the development of plants. This is a very important conclusion for the management of areas colonised by Canadian goldenrod. Currently, according to recommendations, the most common way to eradicate this invasive species on large abandoned agricultural land is mowing (Kabuce and Priede, 2010). In view of the above research results, a very important here seems to be the removal of mown organic matter, which is a source of allelopathic compounds, inhibiting germination and development of native species returning to former habitats.

One of the first effects of allelopathic compounds at the cell level is membrane depolarization. It causes disorders in the transport of anions and cations, which is associated with increased permeability of these structures. Damage to membranous cell structures depends, among others on the concentration and solubility of allelopathic substances and the pH of the environment (Shann and Blum, 1987; Einhellig, 2004). Low pH values may promote the activity of allelopathic compounds released by $S$. canadensis (Wang et al., 2016). In addition, the environmental stress factors increase allelochemical production and thus increase potential toxicity (An, 2005). The conducted studies showed an increase in the destabilisation of cell membranes in the presence of extracts from $S$. canadensis. Depending on the type of extract and the substances it contains, their 
actions resulted in a lower or higher electrolytes leakage, indicating the stress of plants treated with extracts (Figure 4). Disturbances of water-ion economy have a consequent effect on the course of other life processes of plants. For example, they play an important role in the production of chlorophyll, which is responsible for photochemical reactions. In this experiment, clover seedlings were characterised by different content of chlorophylls; the most negative effects were observed with macerate and infusion (Figure 3). Usually, when the concentration of allelopathic compounds increases in extracts, there is a significant reduction in the chlorophyll content (Puła et al., 2020).

The sensitivity and reactive ability on the changes in the environment are an important mechanism of ecological invasion. An explanation in terms of physiological and ecological adaptation of alien invasive plants to the environment would certainly help to introduce effective and synthetic schemes to destruction of them. It would also facilitate forecasting potential distribution areas and estimating threats to other native flora species. To the control of invasive plants such as $S$. canadensis, attention should be paid to their scattered populations, monitored so that they are not a secondary source for seed dispersion (Hua et al., 2007). It is also worth look for among native species of plants that are relatively resistant to allelopathic compounds and can pave the way for re-colonisation of areas colonised by alien invasive plants. In the light of other experiments, legumes are relatively good for this (Chen et al., 2005; Yang et al., 2007).

\section{Conclusions}

(1) The results presented in this study confirm allelopathic properties of various types of the aqueous extracts from Solidago canadensis dry leaves; chemical compounds contained in goldenrod leaves had a negative effect on Trifolium pratensecv. 'Rozeta' germination indexes. (2) Biometric analysis of clover seedlings revealed significant growth inhibition in the presence of infusion and macerate on T. pratense seedlings. (3) Each of the extracts used had a negative effect on fresh weight; the highest decrease in the value of these parameters was recorded for seedlings germinated on macerate. Dry weight was increased in all extracts, compared to the control values. (4) The aqueous extracts reduced chlorophyll content in clover seedlings; the most negative effects were caused by macerate and infusion. (5) The negative effect of aqueous extracts from $S$. canadensis leaves was confirmed by electrolyte leakage; water-ion disturbances were weaker in seedlings germinated on the decoction and infusion than in those watered with the macerate. (6) Macerate as a type of solution, is the closest to the natural extraction from dead organic debris, and its allelopathic effect is in this case the largest, so when performing treatments eliminating goldenrod, which is an important source of allelochemical compounds that inhibit germination and growth of other plants.

\section{Authors' Contributions}

Conceptualization: PZ, BBK,KM; Formal analysis: KM, BBK, PZ, AS-S; Funding acquisition BB-K; Investigation: BB-K, KM, PZ, JP; Methodology: KM, BB-K, PZ; Project administration: PZ, KM, BB-K, JP; Resources: KM, BB-K, PZ, AS-S; Software: BB-K, PZ, AS-S, JP; Visualization: PZ, KM, BB-K, AS-S; Writing - original draft: KM, BB-K, PZ, AS-S; Writing - review and editing: PZ, KM, BB-K.

All authors read and approved the final manuscript. 


\section{Acknowledgements}

This study was financially supported by the Pedagogical University of Krakow Grant: Ecophysiological properties of invasive plants in natural and anthropogenic habitats: the importance of the phenomenon of allelopathy - part I. (signature: WPBU/2020/05/00172; registration number: BN.610-169/PBU/2020).

\section{Conflict of Interests}

The authors declare that there are no conflicts of interest related to this article.

\section{References}

Abhilasha D, Quintana N, Vivanco J, Joshi J (2008). Do allelopathic compounds in invasive Solidago canadensis s.l. restrain the native European flora? Journal of Ecology 96(5):993-1001. https://doi.org/10.1111/j.13652745.2008.01413.x

An M (2005). Mathematical modelling of dose-response relationship (hormesis) in allelopathy and its application. Nonlinearity in Biology, Toxicology and Medicine 3(2):153-172. https://dx.doi.org/10.2201\%2Fnonlin.003.02.001

Barnes JD, Balaguer L, Manrique E, Elvira, S, Davison AW (1992). A reappraisal of the use of DMSO for the extraction and determination of chlorophylls $\mathrm{a}$ and $\mathrm{b}$ in lichens and higher plants. Environmental and Experimental Botany 32(2):85-100. https://doi.org/10.1016/0098-8472(92)90034-Y

Bartoszek W, Stachurska-Swakoń A (2016). Gypsophila perfoliata (Caryophyllaceae) in Poland. Polish Botanical Journal 61(2):257-262. http://dx.doi.org/10.1515/pbj-2016-0030

Bing-Yao S, Jian-Zhong T, Zhi-Gang T, Fu-Gen G, Ming-De Z (2006). Allelopathic effects of extracts from Solidago canadensis L. against seed germination and seedling growth of some plants. Journal of Environmental Sciences 18(2):304-309.

Black M, Pritchard HW (2002). Desiccation and survival in plants: Drying without dying. CAB International Wallingford, United Kingdom.

Butcko VM, Jensen RJ (2002). Evidence of tissue-specific allelopathic activity in Euthamia graminifolia and Solidago canadensis (Asteraceae). The American Midland Naturalist 148(2):253-262. https://doi.org/10.1674/00030031(2002)148[0253:EOTSAA]2.0.CO;2

Chen X, Mei LX, Tang JJ (2005). Allelopathic effects of invasive Solidago canadensis on germination and root growth of native Chinese plants. The Regional Institute - online publishing: Retrieved 2020 September 09 from http://www.regional.org.au/au/allelopathy/2005/2/1/2503_chena.html

Czerwińska E, Szparaga A, Deszcz E (2015). Estimation of effect of dressing in plant extracts on germination capacity of yellow lupine and field pea seed. Zeszyty Naukowe Uniwersytetu Przyrodniczego we Wrocławiu, Rolnictwo 113(612):7-19.

Domaradzki K, Sekutowski TR, Jezierska-Domaradzka A, Matkowski A, Stochmal A (2017). Aktywność herbicydowa wyciągów wodnych z dwóch gatunków z rodzaju Solidago w stosunku do Thlaspi arvense i Stellaria media (Comparison the herbicidal activity of water extracts from two Solidago species against Thlaspi arvense and Stellaria media). Polish Journal of Agronomy 31:11-15.

Einhellig FA (2004). Mode of allelochemical action of phenolic compounds. In: Macias FA, Galindo JCG, Jose M, Molinillo G (Eds). Allelopathy: Chemistry and mode of action of allelochemicals. CRC Press, London pp 217 374.

Gao X, Li M, Gao Z, Li C, Sun Z (2009). Allelopathic effects of Hemistepta lyrata on the germination and growth of wheat, sorghum, cucumber, rape, and radish seeds. Weed Biology and Management 9(3):243-249. https://doi.org/10.1111/j.1445-6664.2009.00345.x

Guzikowa M, Maycock PF (1986). The invasion and expansion of three North American species of goldenrod Solidago canadensis L. sensu lato, S. gigantea Ait. and S. graminifolia(L.) Salisb. in Poland. Acta Societatis Botanicorum Poloniae 55(3):367-384. https://doi.org/10.5586/asbp.1986.034 
Hierro JL, Callaway RM (2003). Allelopathy and exotic plant invasion. Plant and Soil 256(1):29-39. https://doi.org/10.1023/A:1026208327014

Hobbs RJ (2002). Land use changes and invasions. In: Mooney HA, Hobbs RJ (Eds). Invasive species in a changing world. Washington, DC: Island Press.

Hua H, Shuiliang G, Guoqi C (2007). Reproductive biology in an invasive plant Solidago canadensis. Frontiers of Biology in China 2(2):196-204. https://doi.org/10.1007/s11515-007-0030-6

Inderjit, Callaway RM, Vivanco JM (2006). Can plant biochemistry contribute to understanding of invasion ecology? Trends Plant Science.11(2):574-580. https://doi.org/10.1016/j.tplants.2006.10.004

Inderjit, Duke SO (2003). Ecophysiological aspects of allelopathy. Planta 217(4):529-539. https://doi.org/10.2307/23388096

Islam AKMA, Anuar N, Yaakob Z (2009). Effect of genotypes and pre-sowing treatments on seed germination behaviour of Jatropha. Asian Journal of Plant Sciences 8(6):433. http://dx.doi.org/10.3923/ajps.2009.433.439

Kabuce N, Priede N (2010). Invasive alien species fact sweet - Solidago canadensis. Online database of the European network on invasive alien species - NOBANIS, www.nobanis.org.

Lu JZ, Weng ES, Wu XW, Weber E, Zhao B, Li B (2007). Potential distribution of Solidago canadensis in China. Acta Phytotaxonomica Sinica 45:670-674. http://dx.doi.org/10.1360/asp06200

Masło D, Najberek K (2014) Amerykańskie nawłocie kontra polskie motyle dzienne [American goldenrod versus Polish daytime butterflies]. In: Mirek Z, Nikel A (Eds). Ochrona przyrody w Polsce wobec współczesnych wyzwań cywilizacyjnych [Nature protection in Poland in the face of contemporary civilization challenges]. Kraków: Komitet Ochrony Przyrody PAN pp 189-195.

Mominul Islam AKM, Kato-Noguchi H (2012). Allelopathic potentiality of medicinal plant Leucas aspera. International Journal of Sustainable Agriculture 4(1):1-7.

Moroń D, Lenda M, Skórka P, Szentgyörgyi H, Settele J, Woyciechowski M (2009). Wild pollinator communities are negatively affected by invasion of alien goldenrods in grassland landscapes. Biological Conservation 142(7):1322-1332. https://doi.org/10.1016/j.biocon.2008.12.036

Możdżeń K, Barabasz-Krasny B, Zandi P, Kliszcz A, Puła J (2020). Effect of aqueous extracts from Solidago canadensis L. leaves on germination and early growth stages of three cultivars of Raphanus sativus L. var. radicula Pers. Plants 9:1549. https://doi.org/10.3390/plants9111549

Pejchar L, Mooney H (2002). Invasive species, ecosystem services and human well-being. Trends in Ecology and Evolution 24(9):497-504. http://dx.doi.org/10.1016/j.tree.2009.03.016

Pimentel D (2011). Biological Invasion: economic and environmental costs of alien plant, animal and microbe species. New York, CRC Press, Taylor and Francis Group, Boca Raton-London.

Puła J, Zandi P, Stachurska-Swakoń A, Barabasz-Krasny B, Możdżeń K, Wang Y (2020). Influence of alcoholic extracts from Helianthus annnus L. roots on the photosynthetic activity of Sinapis alba L. cv. Barka plants. Acta Agricultura Scandinavica, Section B, Soil and Plant Science 70(1):8-13. https://doi.org/10.1080/09064710.2019.1661509

Pyšek P, Jarošik V, Hulme P, Kühn I, Wild J, Arianoutsou M, ... Winter M (2010). Disentangling the role of environmental and human pressures on biological invasions across Europe. PNAS 107(27):12157-12162. https://doi.org/10.1073/pnas.1002314107

Pyšek P, Richardson DM (2010). Invasive species, environmental change and management, and health. Annual Review of Environment and Resources 100(1):45-52. https://doi.org/10.1146/annurev-environ-033009-095548

Redmann RE, Haraldson J, Gusta LV (1986). Leakage of UV-absorbing substances as a measure of salt injury in leaf tissue of woody species. Physiologia Plantarum 67(1):87-91. https://doi.org/10.1111/j.1399-3054.1986.tb01267.x

Rejmánek M, Richardson D, Higgins S, Pitcairn MJ, Grotkopp E (2005). Ecology of invasive plants: State of the art. In: Harold A, Mooney (Eds). Invasive alien species: Searching for solutions. DC: Island Press, Washington.

Richardson DM, Pyšek P (2012). Naturalization of introduced plants: ecological drivers of biogeographical patterns. New Phytologist 196(2):383-396. https://doi.org/10.1111/j.1469-8137.2012.04292.x

Rosef L, Ingebrigtsen HH, Heegaard E (2019). Vegetative propagation of Solidago canadensis- do fragment size and burial depth matter? Weed Research 60(2):132-141. https://doi.org/10.1111/wre.12395

Semple JC, Cook RE (2006). Flora of North America. Magnoliophyta: Asteridae, Part 7: Asteraceae. Oxford University Press, New York, and Oxford.

Shann JR, Blum U (1987). The uptake of ferulic acid and p-hydroxybenzoic acids by Cucumis sativus. Phytochemistry 26(11):2959-2964. https://doi.org/10.1016/S0031-9422(00)84571-9 
Skórka P, Lenda M, Tryjanowski P (2010). Invasive alien goldenrods negatively affect grassland bird communities in Eastern Europe. Biological Conservation 143(4):856-861. https://doi.org/10.1016/j.biocon.2009.12.030

Sołtys-Lelek A, Barabasz-Krasny B (2010). Ekspansja wybranych gatunków obcego pochodzenia we florze i szacie roślinnej Ojcowskiego Parku Narodowego (Południowa Polska) (Expansion of selected species of foreign origin in the flora and vegetation of the Ojców National Park (Southern Poland)). Prądnik. Prace Muzealne im. Władysława Szafera 20:333-376.

Sun BJ, Tan JZ, Wan ZG, Gu FG, Zhu MD (2006). Allelopathic effects of extracts from Solidago canadensis L. against seed germination and seedling growth of some plants. Journal of Environmental Sciences 18(2):304-309.

Sun ZK, He WM (2010). Evidence for enhanced mutualism hypothesis: Solidago canadensis plants from regular soils perform better. PLoS ONE 5:e15418. https://doi.org/10.1371/journal.pone.0015418

Szymura M, Wolski K (2006). Zmiany krajobrazu pod wpływem ekspansywnych bylin północnoamerykańskich z rodzaju Solidago L. [Landscape changes under the influence of expansive North American perennials of the genus Solidago L.] Problemy Ekologii Krajobrazu 16:451-460.

Szymura TH, Szymura M, Zając M, Zając A (2018). Effect of anthropogenic factors, landscape structure, land relief, soil and climate on risk of alien plant invasion at regional scale. Science of the Total Environment 626:1373-1381. https://doi.org/10.1016/j.scitotenv.2018.01.13

Tokarska-Guzik B, Dajdok Z, Zając M, Zając A, Urbisz A, Danielewicz W, Hołdyński C (2012). Rośliny obcego pochodzenia w Polsce ze szczególnym uwzględnieniem gatunków inwazyjnych [Plants of foreign origin in Poland, with particular emphasis on invasive species]. Warszawa, Generalna Dyrekcja Ochrony Środowiska pp 196.

Towpasz K, Stachurska-Swakoń A (2018). Occurrence of alien species in the agriculture landscape: a case of Proszowice Plateau (Southern Poland). Annales Universitatis Paedagogicae Cracoviensis Studia Naturae 3:7-21. https://doi.org/10.24917/25438832.3.1

Trzcińska-Tacik H, Stachurska-Swakoń A (2011). Alopecurus myosuroides (Poaceae) as the permanent segetal weed of the Skała vicinity in the Krakow-Częstochowa upland. Fragmenta Floristica Geobotanica Seria Polonica 18(2):221-229.

Voser-Huber ML (1983). Studien an eingebürgerten Arten der Gattung Solidago L. (Studies on naturalized species of the genus Solidago L.) Dissertationes Botanicae 68:1-97.

Wang C, Xiao H, Zhao L, Liu J, Wang L, Zhang F, ... Du D (2016). The allelopathic effects of invasive plant Solidago canadensis on seed germination and growth of Lactuca sativa enhanced by different types of acid deposition. Ecotoxicology 25(3):555-562. https://doi.org/10.1007/s10646-016-1614-1

Yang RY, Mei LX, Tang JJ, Chen X (2007). Allelopathic effects of invasive Solidago canadensis L. on germination and growth of native Chinese plant species. Allelopathy Journal 19(1):241-248.

Yuan YG, Wang B, Zhang SS, Tang JJ, Tu C, Hu SJ, ... Chen X (2013). Enhanced allelopathy and competitive ability of invasive plant Solidago canadensis in its introduced range. Journal of Plant Ecology 6(3):253-263. https://doi.org/10.1093/jpe/rts033

Zając A, Zając M (2015). Distribution of kenophytes in the polish Carpathians and their foreland. Kraków: Nakładem Instytutu Botaniki Uniwersytetu Jagiellońskiego.

Zandi P, Barabasz-Krasny B, Stachurska-Swakoń A, Puła J, Możdżeń K (2018). Allelopathic effects of Stellaria media (L.) Vill. on germination and early stages of growth of Raphanus sativus var. radicula. Annales Universitatis Paedagogicae Cracoviensis Studia Naturae 3:90-99. https://doi.org/10.24917/25438832.3.7

Zhang S, Jin Y, Tang J, Chen X (2009). The invasive plant Solidago canadensis L. suppresses local soil pathogens through allelopathy. Applied Soil Ecology 41(2):215-222. https://doi.org/10.1016/j.apsoil.2008.11.002

Zhang SS, Zhu W, Wang B, Tang JJ, Chen X (2011). Secondary metabolites from the invasive Solidago canadensis L. accumulation in soil and contribution to inhibition of soil pathogen Pythium ultimum. Applied Soil Ecology 48(3):280-286. https://doi.org/10.1016/j.apsoil.2011.04.011

Zhao Y, Padilla-Zakour O, Yang G (2005). Polyphenols, antioxidant and antimicrobial activities of leaf and bark extracts of Solidago canadensis L. Industrial Crops Products 74:803-809. https://doi.org/10.1016/j.indcrop.2015.06.014 
OPEN ACCESS

(c) (2)

The journal offers free, immediate, and unrestricted access to peer-reviewed research and scholarly work. Users are allowed to read, download, copy, distribute, print, search, or link to the full texts of the articles, or use them for any other lawful purpose, without asking prior permission from the publisher or the author.

License - Articles published in Notulae Botanicae Horti Agrobotanici Cluj-Napoca are Open-Access, distributed under the terms and conditions of the Creative Commons Attribution (CC BY 4.0) License. (C) Articles by the authors; UASVM, Cluj-Napoca, Romania. The journal allows the author(s) to hold the copyright/to retain publishing rights without restriction. 